\title{
PENGARUH PENERAPAN METODE PEMBELAJARAN RESOURCE BASED-LEARNING (RBL) DENGAN MEMANFAATKAN INTERNET TERHADAP HASIL BELAJAR BIOLOGI SISWA KELAS X SMA N 4 PADANG TAHUN PELAJARAN 2008/2009
}

\author{
Ardi; Anizam Zein; Rica Rusticawaty \\ Jurusan Biologi FMIPA Universitas Negeri Padang \\ Kampus FMIPA Universitas Negeri Padang Jl. Prof. Dr. Hamka Air Tawar Barat Padang. \\ e-mail: aradinov@yahoo.com
}

\begin{abstract}
This study was conducted to figure out the influence of Resource-based Learning $(R B L)$ learning method using internet toward learning achievement in Biology subject. This study employed Post-test only Control Group Design. The population was the first semester of the tenth grade students of SMAN 4 Padang in 2008/2009 academic year. They were distributed into 8 parallel classes. The sample was taken by employing purposive sampling technique. After deciding two classes to become the sample by using coin flipping technique, class X.6 and X.5 were chosen as the experimental and control groups respectively. Data were analyzed by using t-test. Based on the data analysis, it was found that the value of $t$-calculated was 3.87 under the degree of freedom $95 \%(\alpha=0.05)$ and the value of $t$-table was 2.00 under the degree of freedom of 69. Therefore, $t$-calculated was higher that t-table. This means that the alternate hypothesis was accepted. It can be concluded that Resource-based Learning (RBL) learning method using internet gives significant influence toward learning achievement in Biology subject of the tenth grade students of SMAN 4 Padang in 2008/2009 academic year.
\end{abstract}

Kata kunci: metode pembelajaran, resource based learning, internet, hasil belajar, biologi

\section{PENDAHULUAN}

$\mathrm{D}$ ewasa ini, kondisi dunia pendidikan di Indonesia telah banyak mengalami perubahan dan kemajuan, sehingga tuntutan pembelajaran pun berubah sesuai dengan perkembangan sains dan teknologi serta tuntutan zaman. Lufri (2007) menyatakan bahwa berbagai teori dan pemikiran pendidikan yang muncul telah mendorong lahirnya paradigma baru tentang pendidikan dan pembelajaran, diantaranya seperti: pe- ngetahuan ditemukan dan dikembangkan oleh siswa, sehingga diharapkan siswa dapat membangun pengetahuannya secara aktif. Di lain pihak pendidik hanya bertugas untuk mengembangkan kompetensi anak didik secara optimal.

Menurut Nasution (2008), jika dahulu diutamakan soal mengajar, maka akhir-akhir ini ditonjolkan soal belajar. Belajar akan menjadi suatu hal yang menarik dan berhasil bila bahan pelajaran sesuai dengan kebutuhan dan minat siswa. Setiap anak itu berbeda secara 
individual, jadi minat mereka terhadap pelajaran tidak bisa di homogenkan.

Salah satu usaha untuk mempertimbangkan perbedaan individual siswa itu adalah pembelajaran berdasarkan sumber atau resource-based learning (RBL). RBL merupakan segala bentuk belajar yang langsung menghadapkan murid dengan suatu atau sejumlah sumber belajar secara individual atau kelompok dengan segala kegiatan belajar yang bertalian dengan itu (Nasution, 2008).

Dalam RBL guru bukanlah merupakan sumber belajar satu-satunya. Untuk mencapai hasil belajar yang optimal para siswa tidak cukup hanya mengandalkan guru sebagai sumber belajar. Hal ini disebabkan karena waktu belajar di dalam kelas relatif singkat untuk menyampaikan dan menjelaskan semua materi ajar. Siswa harus diberi kemandirian untuk belajar memanfaatkan berbagai sumber belajar. Pada kondisi seperti ini siswa dituntut untuk lebih aktif mencari informasi mengenai materi ajar maupun informasi terbaru lainnya di luar kelas.

Sumber belajar yang dapat digunakan oleh siswa guna mendukung kegiatan belajarnya sangat beragam jenisnya. Sumber belajar itu dapat diperoleh dari lingkungan maupun pengalaman, asalkan dapat digunakan dan dapat mendukung kegiatan pembelajaran secara lebih efektif dan dapat mempermudah pencapaian tujuan pembelajaran, tersedia baik dengan sengaja disediakan ataupun tidak disengaja, baik yang langsung ataupun tidak langsung, baik yang konkrit maupun yang abstrak (Hamalik, 2003). Beberapa contoh sumber belajar itu diantaranya buku-buku pelajaran, koran, perpustakaan, laboratorium, guru, sesama siswa, radio, televisi, OHP, slide, film dan bahkan ruang kelas dan gedung sekolah dapat dijadikan sebagai sumber belajar. Sejalan dengan itu, kurikulum tahun 2004 mempertegas bahwa proses pembelajaran harus berpusat pada siswa, pengajar bukan sebagai satu-satunya sumber belajar, melainkan berperan sebagai fasilitator, dinamisator dan motivator dalam pengajaran (Andoyo, 2006).

Sehubungan dengan hal di atas, sekarang ini berkembang teknologi internet yang memberikan kemudahan dan keleluasaan dalam menggali ilmu pengetahuan. Siswa dapat memilih internet sebagai salah satu sumber informasi ilmu pengetahuan atau sumber belajar. Melalui internet siswa dapat mengembangkan proses belajarnya dengan mencari referensi dan informasi di internet sehingga wawasan siswa menjadi berkembang. Banyak situs pendidikan yang tersaji di internet yang menyediakan berbagai informasi keilmuan, artikel, informasi sekolah, beasiswa dan lain sebagainya. Informasi yang tersedia di internet lebih up to date dibandingkan dengan bukubuku atau majalah yang dijual di pasaran.

Meskipun internet merupakan sumber informasi yang canggih, tidak berarti internet bisa menggantikan tugas guru sebagai tenaga pendidik. Guru harus dapat menjalankan fungsinya sebagai motivator yang harus merangsang peserta didik untuk mau terlibat menggunakan internet sebagai sumber belajar di luar kelas. Para guru bisa memberikan tugas berupa mencari artikel atau kasuskasus real dan mencari bahan-bahan pelajaran lewat internet. Dalam beberapa materi pelajaran Biologi, metode belajar yang digunakan tidak lagi berupa ceramah, namun lebih kepada diskusi kelas. Tentu saja siswa terlebih dahulu harus mempersiapkan diri dengan informasi yang didapat dari berbagai sumber, termasuk internet.

Bahan-bahan pelajaran yang dibutuhkan dapat diperoleh di internet dengan cepat dengan memanfaatkan fasilitas mesin pencari (search engine) seperti google dan yahoo. Para siswa cukup memasukkan kata kunci yang 
dibutuhkan, dan dalam beberapa detik semua alamat yang memuat bahan materi dengan kata kunci yang dibutuhkan akan ditampilkan. Bukan hanya dengan cara demikian, para siswa juga dapat mengakses langsung beberapa situs seperti www.biologi.lipi.go.id dan www.e-dukasi.net, yang menyediakan materi ajar untuk semua mata pelajaran, termasuk Biologi dari tingkat SMP sampai SMA.

Dengan mengumpulkan bahan pelajaran Biologi di internet beberapa hari sebelum proses belajar mengajar berlangsung, maka diharapkan siswa akan dapat memahami dan mengaitkan informasi yang ditemukannya dengan konsep-konsep Biologi yang berhubungan dengan materi yang akan dibahas. Dengan demikian tingkat penguasaan siswa terhadap materi pelajaran diharapkan akan lebih baik.

Beberapa penelitian terdahulu telah membuktikan pengaruh pemanfaatan internet terhadap hasil belajar siswa. Siahaan (2002) melaporkan bahwa sebagian besar SLTA di wilayah Jakarta dan sekitarnya telah memanfaatkan internet untuk menunjang proses pembelajaran. Selanjutnya Erlina (2007) menyatakan terdapat perbedaan hasil belajar mahasiswa Pendidikan Ekonomi Universitas Negeri Padang yang memanfaatkan internet dengan yang tidak memanfaatkan internet.

Berdasarkan uraian di atas, penulis menduga bahwa hal yang sama juga dapat dilakukan dalam proses pembelajaran Biologi, khususnya di SMA N 4 Padang. Hal ini didukung oleh lokasi dan kondisi lingkungan disekitar SMA N 4 Padang yang terletak dikawasan perkotaan dan pusat pendidikan sampai kepada perguruan tinggi, diimbangi dengan pola pikir masyarakat yang maju dan terbuka terhadap perubahan proses pendidikan. Bagi siswa, internet bukanlah lagi menjadi sesuatu hal yang baru, karena siswa di sekolah ini telah memiliki kemampu- an dasar untuk dapat mengoperasikan perangkat komputer yang telah dilengkapi dengan jaringan internet. Hal ini diperkuat dengan adanya mata pelajaran Teknik Informatika Komputer (TIK) dengan materi internet yang telah mulai diajarkan pada siswa kelas IX SMP se kota Padang.

Dari uraian di atas, penulis telah melakukan penelitian yang berjudul "Pengaruh Penerapan Metode Pembelajaran Resource Based-Learning (RBL) dengan Memanfaatkan Internet Terhadap Hasil Belajar Biologi Siswa Kelas X SMA N 4 Padang Tahun Pelajaran 20082009".

Diharapkan, hasil penelitian ini dapat bermanfaat bagi dinas pendidikan, tenaga pengajar dan acuan bagi peneliti selanjutnya dalam upaya meningkatkan mutu pendidikan melalui pemanfaatan teknologi informasi dan komunikasi, seperti internet.

\section{METODE PENELITIAN}

Jenis penelitian ini adalah penelitian eksperimen yang dirancang dengan menggunakan model Posttest only control group design dengan populasi seluruh siswa kelas X SMA N 4 Padang yang terdaftar pada semester I tahun pelajaran 2008/2009, yang tersebar dalam 8 kelas. Sampel diambil dengan menggunakan teknik purposive sampling.

Dengan mempertimbangkan kemampuan dasar kelas $\mathrm{X}$ yang bersamaan atau mendekati sama dan kesamaan jadwal pembelajaran, maka terpilih kelas X5 dan X6, sebagai kelas sampel. Selanjutnya untuk menentukan kelas eksperimen dan kontrol dilakukan pengundian sehingga diperoleh kelas X5 sebagai kelas kontrol dan kelas X6 sebagai kelas eksperimen. Secara rinci dikemukakan pada Tabel 1 . 
Tabel 1. Jumlah siswa dan rata-rata kemampuan dasar siswa kelas $\mathrm{X}$ SMAN 4 Padang tahun pelajaran 2008/2009

\begin{tabular}{|c|c|c|c|c|}
\hline No & $\begin{array}{c}\text { Kela } \\
\text { s }\end{array}$ & $\begin{array}{l}\text { Jumlah } \\
\text { siswa } \\
\text { (orang) }\end{array}$ & $\begin{array}{c}\text { Rata- } \\
\text { rata } \\
\text { nilai }\end{array}$ & $\begin{array}{c}\text { Keterang } \\
\text { an }\end{array}$ \\
\hline 1. & $\mathrm{X} 1$ & 35 & 68,58 & \\
\hline 2. & $\mathrm{X} 2$ & 40 & 71,54 & \\
\hline 3. & X3 & 40 & 66,33 & \\
\hline 4. & $\mathrm{X} 4$ & 40 & 67,90 & \\
\hline 5. & X5 & 40 & 66,20 & $\begin{array}{c}\text { Kelas } \\
\text { kontrol }\end{array}$ \\
\hline 6. & X6 & 40 & 66,43 & $\begin{array}{c}\text { Kelas } \\
\text { eksperim } \\
\text { en }\end{array}$ \\
\hline 7. & $\mathrm{X} 7$ & 39 & 65,61 & \\
\hline 8. & $\mathrm{X} 8$ & 40 & 68,13 & \\
\hline \multicolumn{5}{|c|}{ Jumlah } \\
\hline & $\begin{array}{l}\text { ber: } \\
\text { ing) }\end{array}$ & Tata & aha & $M A \quad N$ \\
\hline
\end{tabular}

Berdasarkan tujuan penelitian yang telah dikemukakan, maka yang menjadi variabel dalam penelitian ini adalah penggunaan metode RBL dengan memanfaatkan internet sebagai sumber belajar sebagai variabel bebas dan hasil belajar siswa sebagai variabel terikat. Sedangkan data adalah data primer yang diperoleh langsung dari tes akhir yang diberikan pada siswa.

Instrumen yang digunakan untuk mengumpulkan data adalah 40 item soal tes yang berasal dari 50 soal yang telah diujicobakan. Tes yang digunakan, memiliki indeks kesukaran 0,30-0,69 (sukar dan sedang) dan kriteria daya beda 0,211,00 (cukup sampai baik sekali), sedangkan reliabilitasnya adalah 0,74 . Disamping itu juga digunakan angket untuk memantau siswa yang menggunakan internet

Hipotesis yang diajukan, diuji dengan uji beda dua rata-rata (uji t). Sesuai dengan persyaratan penggunaan uji ini, maka terlebih dahulu dilakukan uji normalitas (uji Liliefors) dan uji homogenitas (uji F) sampel.

\section{HASIL DAN PEMBAHASAN}

Dari penelitian yang telah dilakukan pada kedua kelas sampel, diperoleh data tentang hasil belajar siswa. Data tersebut diperoleh dari tes akhir pada kegiatan penelitian yang diikuti oleh seluruh siswa, yaitu sebanyak 40 orang siswa, sedangkan pada kelas kontrol tes akhir hanya diikuti oleh 38 orang siswa dari jumlah keseluruhan 40 orang siswa di kelas tersebut. Dari angket pemanfaatan internet yang diisi oleh siswa, pada kelas eksperimen 2 dari 40 orang siswanya tidak memanfaatkan internet sebagai sumber belajar. Sementara itu, pada kelas kontrol 5 dari 38 peserta tes memanfaatkan internet sebagai sumber belajarnya. Sehingga data tes akhir yang penulis olah dalam penelitian ini adalah data yang berasal dari 71 orang peserta tes, yakni 38 orang siswa dari kelas eksperimen dan 33 orang siswa dari kelas kontrol.

Berdasarkan hasil analisis jawaban siswa pada kegiatan tes akhir, diperoleh data hasil belajar siswa yang terlihat pada Tabel 2 .

Tabel 2. Nilai Rata-rata, Simpangan Baku dan Varians Kelas Eksperimen dan Kelas Kontrol

\begin{tabular}{|c|c|c|c|c|}
\hline Kelas & $\mathrm{n}$ & $\bar{X}$ & $S$ & $S^{2}$ \\
\hline Eksperimen & 38 & 72,30 & 12,59 & 158,51 \\
\hline Kontrol & 33 & 60,30 & 13,52 & 182,80 \\
\hline \multicolumn{5}{|c|}{ Keterangan: } \\
\hline $\mathrm{n}$ & \multicolumn{4}{|c|}{ sgota sampel } \\
\hline $\bar{X}$ & \multicolumn{4}{|c|}{$=$ nilai rata-rata } \\
\hline $\begin{array}{l}S \\
S^{2}\end{array}$ & \multicolumn{4}{|c|}{$=$ simpangan baku } \\
\hline
\end{tabular}

Berdasarkan Tabel 2 dapat dilihat bahwa hasil belajar siswa pada kelas eksperimen yang diberi perlakuan dengan metode belajar resource-based learning (RBL) dengan memanfaatkan 
internet memiliki nilai rata-rata $(72,30)$ yang lebih tinggi daripada hasil belajar siswa pada kelas kontrol $(60,30)$.

Sebelum melakukan pengujian hipotesis, sebagaimana dikemukakan pada metode penelitian, maka telah dilakukan uji normalitas dan uji homogenitas, kemudian dilanjutkan dengan uji hipotesis untuk menentukan statistik mana yang akan digunakan. Berdasarkan uji normalitas kelas ekperimen dan kelas kontrol diperoleh harga $\mathrm{L}_{o}$ dan $\mathrm{Lt}$ pada taraf nyata 0,05 untuk $n>30$ sebagaimana terlihat pada Tabel 3.

Tabel 3. Hasil Uji Normalitas Kelas Eksperimen dan Kelas Kontrol

\begin{tabular}{cccccc}
\hline Kelas & $\mathrm{N}$ & $\alpha$ & $\mathrm{L}_{0}$ & $\mathrm{~L}_{\mathrm{t}}$ & $\begin{array}{c}\text { Kete } \\
\text { rangan }\end{array}$ \\
\hline $\begin{array}{c}\text { Ekspe } \\
\text { rimen }\end{array}$ & 38 & 0,05 & 0,0185 & 0,1437 & Normal \\
\hline $\begin{array}{c}\text { Kont } \\
\text { rol }\end{array}$ & 33 & 0,05 & 0,0439 & 0,1543 & Normal \\
\hline
\end{tabular}

Berdasarkan Tabel 3 terlihat bahwa kedua kelas eksperimen dan kelas kontrol memiliki $\mathrm{L}_{0}<\mathrm{L}_{\mathrm{t}}$, berarti data kedua kelas sampel terdistribusi normal.

Hasil uji homogentitas sampel dikemukakan pada Tabel 4.

Tabel 4. Hasil Uji Homogenitas Kelas Eksperimen dan Kelas Kontrol

\begin{tabular}{lllll}
\hline Kelas & $\alpha$ & $\mathrm{F}_{\text {hitung }}$ & $\mathrm{F}_{\text {Tabel }}$ & Kesimpulan \\
\cline { 1 - 4 } Eksperimen & & & & \\
\hline Kontrol & 0,05 & 1,153 & 1,78 & Homogen \\
\hline
\end{tabular}

Dari Tabel 4 di atas tampak bahwa

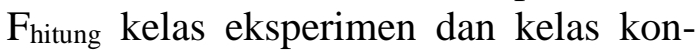
trol lebih kecil dari $\mathrm{F}_{\text {Tabel }}\left(\mathrm{F}_{\text {hitung }}<\mathrm{F}_{\text {Tabel }}\right)$, berarti kelas eksperimen dan kelas kontrol memiliki varians yang homogen.

Berdasarkan uji normalitas dan uji homogenitas kelas eksperimen dan kelas kontrol, maka pengujian hipotesisnya digunakan uji t. Dari perhitungan dengan uji t diperoleh data sebagimana ditampilkan pada Tabel 5.
Tabel 5. Hasil Uji Perbedaan Dua RataRata Tes Akhir

\begin{tabular}{cccc}
\hline Kelas & $\mathrm{t}_{\text {hitung }}$ & $\mathrm{t}_{\text {tabel }}$ & Kesimpulan \\
\hline Eksperimen & & & Hipotesis \\
Kontrol & 3,87 & 2,00 & $\begin{array}{c}\text { Hiterima } \\
\text { dim }\end{array}$
\end{tabular}

Dari hasil perhitungan dengan ujit didapat bahwa harga thitung 3,87 dan pada taraf nyata 0,05 didapat harga $t_{\text {tabel }}$ 2,00 dengan derajat kebebasan 69. Dengan demikian $t_{\text {hitung }}>t_{\text {tabel }}$, maka dapat dikatakan bahwa hipotesis diterima. Dapat disimpulkan bahwa terdapat perbedaan yang berarti dari hasil belajar siswa antara kelas eksperimen yang diberi perlakuan menggunakan metode belajar resource-based learning dengan memanfaatkan internet dibandingkan kelas kontrol yang tidak menggunakan sumber belajar dari internet.

Peningkatan hasil belajar siswa melalui penerapan metode pembelajaran RBL dengan memanfaatkan internet ini disebabkan oleh beberapa hal, satu diantaranya adalah faktor sumber belajar yang di peroleh dari internet. Asumsi ini di dukung oleh pendapat Kenji (1997) dalam Siahaan (2002) menyatakan bahwa ada 3 karakter internet yang dapat dimanfaatkan dalam kehidupan seharihari, diantaranya sebagai alat mengakses informasi dan sebagai alat pendidikan dan pelajaran. Hamalik (2003) menyatakan bahwa berhasil atau tidaknya seseorang dalam belajar diantaranya disebabkan oleh faktor yang berasal dari luar seperti ketersediaan sumber belajar, maupun yang berasal dari dalam diri siswa itu sendiri, seperti motivasi dan minat untuk mempelajari sesuatu.

Peningkatan hasil belajar siswa menggunakan internet juga diduga karena bahan pelajaran dalam internet lebih menarik perhatian siswa dibandingkan dengan apa yang mereka lihat pada buku-buku pelajaran (Oetomo, 2002). 
Sejalan dengan pendapat Sardiman (2007), hal ini dapat meningkatkan motivasi belajar siswa, sehingga berdampak positif terhadap peningkatan hasil belajar siswa pada kelas eksperimen. Lebih lanjut dijelaskan bahwa motivasi belajar akan muncul karena ada kebutuhan dan minat. Proses belajar akan berjalan dengan lancar dan memberikan hasil yang optimal kalau disertai dengan motivasi dan minat untuk belajar. Minat belajar siswa dapat dibangkitkan salah satunya dengan menggu-nakan berbagai macam sumber belajar dan bentuk mengajar.

Internet sebagai sumber belajar dapat diartikan sebagai sumber informasi yang tersedia dalam bentuk media elektronik. Dari tugas yang diberikan kepada siswa di kelas eksperimen, siswa banyak mendapatkan bahan pelajaran dari internet dengan memanfaatkan situs www.edukasi.net. Selain situs tersebut, para siswa juga mengakses beberapa situs lainnya dengan memanfaatkan fasilitas search engine seperti google. Dengan demikian, siswa dapat mengeksplorasi bahan pelajaran yang ditugaskan cukup dengan memasukkan kata kunci yang mereka inginkan.

Dengan menyuruh siswa untuk mencari bahan pelajaran terkait dengan materi yang akan dipelajari di sekolah, berarti guru sebagai tenaga pengajar telah menjalankan peranannya sebagai motivator bagi siswa untuk dapat mengimplementasikan salah satu fungsi internet sebagai alat pendidikan atau pelajaran. Dengan memanfaatkan internet sebagai sumber belajar diharapkan dapat mela-hirkan kaum intelektual muda yang tidak lagi gagap teknologi dan informasi.

Seiring dengan kemajuan teknologi informasi, kepercayaan klasik yang cenderung hanya mempercayai institusi sekolah sebagai satu-satunya sumber belajar disadari tidak dapat lagi diterapkan. Siahaan (2002) menyatakan bahwa dengan memanfaatkan teknologi informasi seperti internet, keterbatasan sumber belajar tidak lagi menjadi permasalahan. Siswa dapat mengembangkan proses belajarnya dengan mengakses berbagai referensi, baik yang berupa hasil penelitian, maupun artikel hasil kajian dalam berbagai bidang. Tidak lagi harus secara fisik datang ke perpustakaan untuk mencari berbagai referensi, sebab internet merupakan perpustakaan yang terbesar dari perpustakaan yang ada di manapun Kitao (2002 dalam Siahaan, 2002)). Lebih lanjut Siahaan (2002) menjelaskan bahwa dengan mengakses internet sebagai sumber belajar, siswa dapat lebih memantapkan pemahaman/ penguasaan mereka terhadap materi pelajaran di samping memperluas wawasan mereka melalui berbagai informasi yang di akses. Hanya saja dibutuhkan motivasi dari dalam diri siswa itu sendiri untuk terlibat aktif dalam memanfaatkan internet untuk dapat meningkatkan hasil belajar.

Jadi di dalam belajar berdasarkan sumber (RBL) ini kepasifan siswa dapat dirubah menjadi belajar aktif. Pada kesimpulannya, belajar berdasarkan sumber yang menjadi prioritas utama adalah mendidik siswa untuk menjadi seseorang yang sanggup belajar dan meneliti sendiri dengan mencari bahan pelajaran dari berbagai sumber, mengembangkan konsep-konsep dan pengembangan keterampilan berpikir secara analitis agar siswa sanggup memecahkan masalah sendiri. Akan sangat tertinggal dunia pendidikan Indonesia, jika tidak bisa memanfaatkan teknologi internet. Walaupun belum akan menyelenggarakan pengajaran maupun pendidikan berbasiskan internet, setidaknya guru mampu dan menganjurkan pemanfaatan resources yang ada di internet sebagai salah satu sumber pembelajaran maupun bahan pengajaran (Adri, 2007).

\section{PENUTUP}

Berdasarkan hasil penelitian, nilai rata-rata Biologi kelas eksperimen 
$(72,30)$ lebih baik dari kelas kontrol $(60,30)$. Hasil pengujian hipotesis menunjukkan bahwa perbedaan nilai ini berarti pada taraf kepercayaan $95 \%$. Maka dapat disimpulkan bahwa penerapan metode pembelajaran Resource based-

\section{DAFTAR RUJUKAN}

Adri, Muhammad. 2007. Pemanfaatan Internet Sebagai Sumber Pembelajaran, (Online), (http:// muhammadadri.wordpress.com, diakses 26 April 2008)

Andoyo. 2006. Pemanfaatan Internet Sebagai Sumber Belajar Oleh Mahasiswa Program Studi Pendidikan Administrasi Perkantoran Fakultas Ilmu Sosial Universitas Negeri Yogyakarta, (Online), (http://www.freewebs.com/gothink clp/artikel, diakses 30 November 2007).

Arikunto, Suharsimi. 2007. Dasar-dasar Evaluasi Pendidikan. Jakarta: Bumi Aksara.

Dimyati dan Mudjiono. 2006. Belajar dan Pembelajaran. Jakarta: Rineka Cipta.

Djafar, 2001. Kontribusi Strategi Pembelajaran terhadap Hasil Belajar. Padang: FIP UNP

Erlina, Rika. 2007. Pemanfaatan Internet Oleh Mahasiswa Pendidikan Ekonomi dan Pengaruhnya Terhadap Hasil Belajar. Skripsi tidak diterbitkan. Padang: Fakultas Ekonomi UNP.

Hamalik, Oemar. 2003. Perencanaan Pengajaran Berdasarkan Pendekatan System. Jakarta: Bumi Akasara.

Lufri., Arlis., Yunus, Yuslidar dan Sudirman. 2006. Strategi Pembelajaran Biologi. Padang: Jurusan Biologi FMIPA UNP. learning (RBL) dengan memanfaatkan internet memberikan pengaruh positif yang berarti terhadap hasil belajar Biologi siswa kelas X SMA N 4 Padang semester I tahun pelajaran 2008/2009.

Mudjijo. 1995. Penilaian Hasil Belajar Siswa. Jakarta: PT. Grafindo Persada.

Nasution, S. 2008. Berbagai Pendekatan Dalam Proses Belajar dan Mengajar. Bandung: Bina Aksara.

Nurkencana, Wayan dan Sumartana. 1986. Evaluasi Pendidikan. Jakarta: Usaha Nasional.

Oetomo, Budi Sutedjo. 2002. eEducation. Konsep, Teknologi dan Aplikasi Internet Pendidikan. Yogyakarta: Penerbit Andi.

Prayitno, Elida. 1993. Motivasi Dalam Belajar. Jakarta: PPLTK.

Renggani. 2007. Model Inovasi Elearning Dalam Meningkatkan Mutu Pendidikan, (Online), (http:// renggani.blogspot.com/2007/07/m akalah-model-inovasi-elearning.html, diakses 7 Desember 2007).

Sadiman, Arief. S. 1989. Media Pengajaran. Jakarta: Pustekom Depdikbud dan CV Rajawali.

Sanjaya, Wina. 2005. Pembelajaran dalam Implementasi Kurikulum Berbasis Kompetensi. Jakarta: Kencana Prehada Media Group.

Sanjaya, Wina. 2006. Strategi Pembelajaran Berorientasi Standar Proses Pendidikan. Jakarta: Prehada Media.

Sardiman. 2007. Interaksi dan Motivasi Belajar-Mengajar. Jakarta: PT. Grafindo Persada. 
121 Ardi dkk, Pengaruh Penerapan Metode Pembelajaran...

Siahaan, Sudirman. 2002. Penelitian Penjajagan Tentang Kemungkinan Pemanfaatan Internet Untuk Pembelajaran di SLTA di Wilayah Jakarta dan Sekitarnya. Jurnal Pendidikan dan Kebudayaan, (Online), Vol. 8, No. 039, (http:// www.dikti.org, diakses 16 Desember 2007).

Sudjana. 2005. Metode Statistik. Bandung: Tarsito.

Winkel, W.S. 1996. Psikologi Pengajaran. Jakarta: Gramedia. 